\title{
KEBEBASAN PENETAPAN MODAL DASAR PERSEROAN TERBATAS OLEH PARA PIHAK BERDASARKAN PERATURAN PEMERINTAH NOMOR 29 TAHUN 2016
}

\author{
I Putu Wisnu Dharma Pura ${ }^{(1)}$, I Nyoman Budiana ${ }^{(2)}$ \\ wisnu.dharma484@gmail.com; nyoman_ny@yahoo.com \\ Undiknas University, Denpasar, Bali
}

\begin{abstract}
Along with the development of law and the community needs that developed rapidly, especially in the globalization era besides the enhancement of public demand for business development in accordance with good corporate governance principles, therefore on August 16, 2007 the Law No. 40 of 2007 was issued, which replace the Law Number 1 of 1995 concerning Limited Liability Companies. Then the enactment of Government Regulation No. 29 of 2016 concerning Changes in Authorized Capital of Limited Liability Company, specifically for beginner entrepreneurs to establish a Limited Liability Company. The provisions of Article 1 paragraph (3) of Government Regulation Number 29 of 2016 regulate: the amount of authorized capital for Limited Liability Company as referred to in paragraph (1) which based on the agreement of the Limited Liability Company founders. Furthermore, in Article 32 paragraph (1) of Law Number 40 Year 2007 concerning Limited Liability Company, regulate that the authorized capital of the Company is at least Rp. 50,000,000.00 (fifty million rupiah). From the above provisions it can be said, there is a norms conflict that cause multiple interpretations and does not provide legal certainty for the parties. Furthermore, the norms regulated in the Government Regulation should be in line with the norms regulated by the law above it, In this case Law Number 40 Year 2007.
\end{abstract}

Keywords : Authorized Capital, Limited Liability Company, Parties

\section{ABSTRAK}

Seiring dengan perkembangan hukum dan kebutuhan masyarakat sehingga pada tanggal 16 Agustus 2007 diundangkan Undang-undang Nomor 40 Tahun 2007 yang menggantikan Undang-undang Nomor 1 Tahun 1995 tentang Perseroan Terbatas. Kemudian berlakunya Peraturan Pemerintah Nomor 29 Tahun 2016 Tentang Perubahan Modal Dasar Perseroan Terbatas, khusus bagi pengusaha pemula untuk mendirikan Perseroan Terbatas. Ketentuan Pasal 1 ayat (3) Peraturan Pemerintah Nomor 29 Tahun 2016 menentukan: besaran modal dasar Perseroan Terbatas sebagaimana dimaksud pada ayat (1) ditentukan berdasarkan kesepakatan para pendiri Perseroan Terbatas. Selanjutnya, dalam Pasal 32 ayat (1) Undang-undang Nomor 40 Tahun 2007 tentang Perseroan Terbatas, menentukan modal dasar Perseroan paling sedikit Rp. $50.000 .000,00$ (lima puluh juta rupiah). Dari ketentuan tersebut diatas maka dapat dikatakan, terdapat konflik norma yang menimbulkan multitafsir dan tidak memberikan kepastian hukum bagi para pihak. Selain itu semestinya bahwa secara tata urutan perundang-undangan norma yang diatur dalam Peraturan Pemerintah seharusnya sejalan dengan norma yang diatur dengan Undang-undang di atasnya, Dalam hal ini Undang-undang Nomor 40 Tahun 2007.

Kata Kunci : Modal Dasar, Perseroan Terbatas, Para Pihak 


\section{PENDAHULUAN}

Berlakunya Peraturan Pemerintah Nomor 29 Tahun 2016 Tentang Perubahan Modal Dasar PT, khusus bagi pengusaha pemula untuk mendirikan PT. Penyesuaian tersebut dimaksudkan untuk memberikan kemudahan berusaha serta menjamin ketertiban dunia usaha dalam investasi dengan mengubah besaran modal dasar yang dirasakan masih sangat memberatkan para pengusaha pemula. Ketentuan pasal 1 Peraturan Pemerintah Nomor 29 Tahun 2016 menentukan:

(1) Perseroan Terbatas wajib memiliki modal dasar perseroan.

(2) Modal dasar Perseroan Terbatas harus dituangkan dalam anggaran dasar yang dimuat dalam akta pendirian Perseroan Terbatas.

(3) Besaran modal dasar Perseroan Terbatas sebagaimana dimaksud pada ayat (1) ditentukan berdasarkan kesepakatan para pendiri Perseroan Terbatas.

Selanjutnya, dalam pasal 32 Undang-undang Nomor 40 Tahun 2007 tentang Perseroan Terbatas, menentukan:

(1) Modal dasar Perseroan paling sedikit Rp. 50.000.000,00 (lima puluh juta rupiah).

(2) Undang-undang yang mengatur kegiatan usaha tertentu dapat menentukan jumlah minimal modal Perseroan yang lebih besar daripada ketentuan modal dasar sebagaimana dimaksud pada ayat (1).

(3) Perubahan besarnya modal dasar sebagaimana dimaksud pada ayat (1), ditetapkan dengan Peraturan Pemerintah.

Berdasarkan ketentuan tersebut diatas dapat dikatakan, bahwa terdapat konflik norma pada pasal 1 ayat (3) Peraturan Pemerintah Nomor 29 Tahun 2016 yang mengatakan besaran modal dasar PT sebagaimana dimaksud pada ayat (1) ditentukan berdasarkan kesepakatan para pendiri PT dengan pasal 32 ayat (1) Undang-undang Nomor 40 Tahun 2007 yang menyatakan modal dasar Perseroan paling sedikit Rp. 50.000.000,00 (lima puluh juta rupiah).

Ketidaksingkronan pengaturan besar modal untuk modal awal PT ini menimbulkan kesulitan pelaksanan kepastian hukum dengan pihak ketiga agar terlindungi ketika melakukan kerjasama atau mitra dengan suatu Perseroan Terbatas. Suatu contoh, ada sengketa dengan pihak 
ketiga tetapi aset perusahaan tidak menutupi utang dengan pihak ketiga. Akhirnya, untuk menutupi utang itu sampai harus terbawa hingga harta pribadi meskipun pertanggungjawaban PT normalnya hanya sebatas modal yang ditanamkan. Berdasarkan uraian diatas penulis tertarik untuk mengkaji permasalahan tentang Kebebasan Penetapan Modal Dasar Persroan Terbatas Oleh Para Pihak Berdasarkan Peraturan Pemerintah Nomor 29 Tahun 2016

\section{TINJAUAN PUSTAKA}

\section{Pengertian Perseroan Terbatas}

Menurut Soedjono Dirjosisworo, PT adalah badan hukum yang didirikan berdasarkan perjanjian, melakukan kegiatan usaha dengan modal dasar yang seluruhnya terbagi dalam saham dan memenuhi persyaratan yang ditetapkan dalam Undang-Undang. ${ }^{1}$

Menurut Abdulkadir Muhammad istilah "perseroan" menunjuk kepada cara menentukan modal, yaitu bagi dalam saham, dan istilah "terbatas" menunjuk kepada batas tanggung jawab pemegang saham, yaitu sebatas jumlah nominal saham yang dimiliki. PT adalah perusahaan persekutuan badan hukum. ${ }^{2}$

R. Ali Rido juga berpendapat bahwa PT adalah suatu bentuk perseroan yang menyelenggarakan perusahaan, didirikan dengan suatu perbuatan hukum bersama oleh beberapa orang, dengan modal tertentu yang terbagi atas saham-saham, yang para anggotanya dapat memiliki satu atau lebih saham dan bertanggung jawab terbatas sampai jumlah saham yang dimilikinya. ${ }^{3}$

PT adalah badan hukum yang didirikan berdasarkan perjanjian, melakukan kegiatan usaha dengan modal saham yang seluruhnya terbagi dalam saham, dan memenuhi persyaratan yang ditetapkan dalam Undang-

1Soedjono Dirjosisworo, 1997, Hukum Perusahaan Mengenai Bentukbentuk Perusahaan (Badan Usaha) di Indonesia, Mandar Maju Bandung, h.48.

2Abdulkadir Muhammad, 2002, Hukum Perusahaan Indonesia, Citra Aditya Bakti, Bandung, h.68.

${ }_{3}$ R. Ali Rido, 1986, Hukum Dagang tentang Aspek-aspek Hukum dalam Asuransi Udara, Asuransi Jiwa dan Perkembangan Perseroan Terbatas, Remadja Karya, Bandung, h.335. 
Undang ini disertakan serta peraturan pelaksanaannya. ${ }^{4}$

Maka pengertian dari PT adalah bentuk usaha yang berbadan hukum dan didirikan bersama oleh beberapa orang, dengan modal tertentu yang terbagi atas saham-saham, yang para anggotanya dapat memiliki satu atau lebih saham dan bertanggung jawab terbatas sampai jumlah saham yang dimilikinya.

\section{Perseroan Terbatas Sebagai Badan Hukum}

PT merupakan salah satu pilar pembangunan perekonomian nasional perlu diberikan landasan hukum yang kuat untuk lebih memacu pembangunan nasional yang disusun sebagai usaha bersama berdasarkan asas kekeluargaan, dengan tetap memunculkan prinsip-prinsip keadilan dalam berusaha. PT berbentuk badan hukum yang didirikan berdasarkan perjanjian untuk melakukan kegiatan dengan modal dasar yang seluruhnya terbagi dalam saham, serta memenuhi persyaratan yang ditentukan oleh undang-undang dan peraturan pelaksananya. PT merupakan yang berhak menjadi pemegang hak dan kewajiban, termasuk menjadi pemilik suatu benda atau harta kekayaan tertentu. PT adalah badan hukum yang merupakan artificial person, yaitu sesuatu yang diciptakan oleh hukum untuk memenuhi perkembangan kebutuhan kehidupan masyarakat. ${ }^{5}$

\section{Jenis-Jenis Perseroan Terbatas}

PT termasuk suatu bentuk perusahaan yang paling popular dalam bisnis dan paling banyak digunakan oleh para pelaku bisnis di Indonesia dalam menjalankan kegiatan usaha diberbagai bidang. Berdasarkan jenis Perseroan, maka PT dibagi menjadi:

1) PT-Non Fasilitas Umum atau PT. Biasa;

2) PT-Fasilitas PMA;

3) PT-Fasilitas PMDN;

4) PT-Persero BUMN;

5) PT-Perbankan;

6) PT-Lembaga Keuangan Non Perbankan;

7) PT-Usaha Khusus. ${ }^{6}$

4I.G Rai Widjaya, 2000, Hukum Perusahaan dan Undang-undang dan Peraturan Pelaksana di Bidang Usaha, KBI, Jakarta, h.127

${ }_{5}$ Frans Satrio Wicaksono, 2009, Tanggungjawab Pemegang Saham, Direksi, dan Komisaris PT(PT), Visimedia, Jakarta, h.2.

${ }_{6}$ R.T Sutantya R. Hadikusuma dan Sumantoro, 1995, Pengertian Pokok 
Berdasarkan penanaman modalnya, jenis PT terbagi menjadi:

1) PT dalam rangka Penanaman Modal Asing (PT-PMA),

2) PT dalam rangka Penanaman Modal Dalam Negeri (PT-PMDN),

3) PT yang modalnya dimiliki oleh Warga Negara Indonesia/Badan Hukum Indonesia (PT- Swasta Nasional),

4) PT-Perseroan BUMN, PT yang telah go public yaitu perusahaan yang sebagian modalnya telah dimiliki publik dengan jalan membeli saham lewat pasar modal (capital market) melalui bursa-bursa saham. ${ }^{7}$

Menurut Sanusi Bintang dan Dahlan terdapat dua macam PT, yaitu:

1) PT Tertutup yang disingkat PT, merupakan Perseoan Terbatas yang modalnya dimiliki para pemegang saham yang masih saling mengenal satu sama lainnya, misalnya anggota keluarga, sahabat, kenalan, dan tetangga yang pendiriannya tunduk pada UUPT.

2) PT Terbuka, yang pada nama perusahaannya memakai singkatan PT (pada awal) dan Tbk (pada akhir) nama PT tersebut, dalam PT Terbuka pemegang sahamnya sudah tidak saling mengenal lagi bahkan melintasi batas negara. ${ }^{8}$

\section{Modal Perseroan}

Istilah modal merupakan istilah yang dikenal dalam kegiatan bisnis maupun dalam bahasa perundang-undangan. Penanaman modal atau investasi adalah penyerahan sejumlah uang yang digunakan sebagai modal dalam suatu perusahaan atau proyek dengan tujuan untuk memperoleh keuntungan atau laba. ${ }^{9}$

Menurut Pasal 31 Undang Undang Nomor 40 Tahun 2007 tentang Perseroan terbatas, modal dasar perseroan terdiri atas seluruh nilai nominal saham dan ketentuan sebagaimana dimaksud dengan modal dasar tidak menutup kemungkinan peraturan perundang-undangan di

Hukum Perusahaan: Bentuk-Bentuk Perusahaan yang Berlaku di Indonesia, Edisi ke-1 Cetakan ke-3, Raja Grafindo Persada, Jakarta, h.40

7 lbid

8 Sanusi Bintang dan Dahlan, 2000, Pokok-pokok Hukum Ekonomi dan Bisnis, Citra Aditya Bakti Bandung, h.33.

9Dhaniswara Harjono, 2007, Hukum Penanaman Modal Tinjauan Terhadap Pemberlakuan Undang-undang No. 25 Tahun 2007 Tentang Penanaman Modal Edisi Pertama, Rajawali Pers, Jakarta, h. 10. 
bidang pasar modal mengatur modal perseroan terdiri atas saham tanpa nilai nominal. Modal dasar perseroan paling sedikit lima puluh juta rupiah dan paling sedikit $25 \%$ (dua puluh lima persen) dari modal dasar harus ditempatkan dan disetor serta dibuktikan dengan bukti penyetoran yang sah, serta pengeluaran saham lebih lanjut yang dilakukan untuk menambah modal yang ditempatkan harus disetor penuh (Pasal 32 dan 33 UUPT Nomor 40 Tahun 2007).

Namun dalam Peraturan Pemerintah Nomor 29 Tahun 2016 Tentang Perubahan Modal Dasar Perseroan Terbatas, Ketentuan pasal 1 ayat (3) Peraturan Pemerintah Nomor 29 Tahun 2016 menentukan:

"Besaran modal dasar PT sebagaimana dimaksud pada ayat (1) ditentukan berdasarkan kesepakatan para pendiri Perseroan Terbatas"

Penambahan modal perseroan dapat dilakukan berdasarkan persetujuan Rapat Umum Pemegang Saham (RUPS). Keputusan Rapat Umum Pemegang Saham (RUPS) untuk penambahan modal dasar adalah sah jika dilakukan dengan memperhatikan persyaratan kuorum dan jumlah suara setuju untuk perubahan anggaran dasar, sesuai dengan ketentuan dalam undang-undang perseroan dan/atau anggaran dasar.

\section{Tanggung Jawab Pemegang Saham Perseroan Terbatas}

Hukum perseroan seperti yang dirumuskan pada Pasal 3 ayat (1) UUPT No. 40 Tahun 2007, secara imajiner membentangkan tembok pemisah antara perseroan dengan pemegang saham untuk melindungi pemegang saham dari segala tindakan, perbuatan dan kegiatan perseroan berupa: ${ }^{10}$

a. Tindakan, perbuatan dan kegiatan perseroan bukan tindakan pemegang saham.

b. Kewajiban dan tanggung jawab perseroan bukan kewajiban dan tanggung jawab pemegang saham. Jika demikian halnya, perseroan sebagai badan hukum, adalah mahluk hukum (a creature of the law) yang memiliki hal-hal berikut:

10 Philip J. Scaletta Jr., dalam Zaman Hadi, 2011, Karakteristik Tanggung Jawab Pribadi Pemegang Saham, Komisaris dan Direksi dalam Perseroan Terbatas, UB Press, Malang, h.31 
1. Kekuasaan (power) dan kapasitas yang dimilikinya karena diberikan hukum kepadanya, dan berwenang berbuat dan bertindak sesuai dengan kewenangan yang diberikan, dalam anggaran dasar (AD).

2. Mempunyai kekuasaan yang diatur secara tegas (express power) seperti untuk memiliki kekayaan, menggugat dan digunakan atas nama perseroan.

3. Tetapi ada juga kekuasaan yang bersifat (implicit power) yakni berwenang melakukan apa saja, asal dilakukan dengan reasonable dan penting (reasonably necessary) untuk perseroan, seperti menguasai atau mentransfer barang, meminjamkan uang, memberi sumbangan dan sebagainya.

Tindakan yang jatuh di luar kekuasaan yang disebut dengan tegas (express power) maupun kekuasaan implisit (implicit power), dapat dikatakan ultra virus yang berarti berada di luar kegiatan dan di luar wewenang. Menurut ketentuan hukum perusahaan terjadi pemisahan dan perbedaan antara perseroan dengan pemilik atau pemegang saham. Pemisahan dan perbedaan terjadi, terhitung sejak perseroan mendapat keputusan pengesahan dari Menteri Hukum dan HAM yang digariskan Pasal 9 ayat (1) UUPT No. 40 Tahun 2007: (1) sejak tanggal pengesahan tersebut, perseroan terpisah dari pemegang saham, pendiri dan pengurus dan (2) juga sejak saat itu perseroan berbeda dari person hukum yang lain.

\section{METODE PENELITIAN}

\section{Desain Penelitian}

Mengkaji tentang adanya konflik norma pada Undang-undang nomor 40 Tahun 2007 Pasal 32 ayat (1) dengan Peraturan Pemerintah nomor 29 Tahun 2016 Pasal 1 ayat (3) karena adanya ketidaksingkronan tentang pengaturan modal awal perusahaan yang semula dalam Undangundang nomor 40 Tahun 2007 ditentukan paling sedikit Rp. 50.000.000,00 kemudian dalam Peraturan Pemerintah nomor 29 Tahun 2016 disebutkan besaran modal dasar PT dtentukan berdasarkan kesepakatan kedua belah pihak. Hal ini justru tidak memberikan sama sekali kepastian hukum bagi para pihak. Oleh karena itu penulis tertarik untuk mengkaji permasalahan ini dengan teori-teori hukum seperti Teori Jenjang/Stuffen Theory, Teori Sistem Hukum, Asas Kepastian Hukum, Asas Lex Superiori Derogat Lex 
Inferiori, Teori Perlindungan Hukum, agar dapat dipahami menjawab rumusan-rumusan masalah diatas.

\section{Jenis dan Sumber Data}

Pada penelitian hukum normatif, bahan pustaka merupakan data dasar yang dalam (ilmu) penelitian digolongkan sebagai data sekunder. Bahan hukum dapat diklasifikasikan menjadi 3 yaitu: ${ }^{11}$

1. Bahan hukum primer

Yaitu bahan hukum yang mempunyai kekuatan mengikat secara umum (perundang-undangan) atau mempunyai kekuatan mengikat bagi pihakpihak berkepentingan (kontrak, konvensi, dokumen, hukum dan putusan hakim).

2. Bahan hukum sekunder

Yaitu bahan hukum yang memberi penjelasan terhadap bahan hukum primer (buku ilmu hukum, jurnal hukum, laporan hukum, media cetak atau elektronik).

\section{Bahan hukum tersier}

Yaitu bahan hukum yang memberi penjelasan terhadap bahan hukum premier dan bahan hukum sekunder (rancangan undang-undang, kamus hukum dan ensiklopedia).

Bahan-bahan hukum sebagai kajian normatif sebagian besar dapat diperoleh melalui penelusuran terhadap berbagai dokumen hukum. ${ }^{12}$ Bahan hukum primer yaitu bahan-bahan hukum yang mengikat, ${ }^{13}$ dalam penulisan ini bahan hukum primer yang digunakan adalah:

1. Undang-undang Dasar Republik Indonesia tahun 1945.

2. Kitab Undang-undang Hukum Perdata.

3. Kitab Undang-undang Hukum Dagang.

4. Undang-undang No. 40 Tahun 2007 tentang Perseroan Terbatas.

5. Peraturan Pemerintah No. 29 Tahun 2016 tentang Perubahan Modal Dasar Perusahaan

11 Abdulkadir Muhammad, 2004, Hukum dan Penelitian Hukum, Citra Aditya Bakti, Bandung, h.82

12 Bahder Johan Nasution, 2008, Metode Penelitian Hukum, Mandar Maju, Bandung, h. 98.

${ }_{13}$ Zainuddin Ali, 2010, Metode Penelitian Hukum, Sinar Grafika, Jakarta, 


\section{Teknik Pengumpulan Data}

Teknik pengumpulan bahan hukum yang dipergunakan dalam penulisan ini adalah studi kepustakaan. Studi kepustakaan merupakan segala usaha yang dilakukan oleh peneliti untuk menghimpun informasi yang relevan dengan topik atau masalah yang akan atau sedang diteliti. Informasi itu diperoleh dari buku-buku ilmiah, laporan penelitian, peraturanperaturan dan sumber-sumber tertulis baik tercetak maupun elektronik lain. Teknik pengumpulan bahan hukum sesuai dengan jenis pendekatan yang digunakan, karena peelitian ini menggunakan jenis pendekatan Undangundang, maka dikumpulkanlah peraturan perundang-undangan yang terkait dengan penelitian ini. Setelah dilakukan studi kepustakaan, kemudian dilanjutkan dengan kualifikasi fakta dan kualifikasi hukum.

\section{Teknik Analisis Data}

Bahan hukum yang telah terkumpul dan dilakukan analisis, setelah mendapatkan suatu informasi atau pemikiran terhadap permasalahan yang diajukan maka bahan hukum tersebut disajikan dengan teknik deskriptif. Dalam penelitian ini diuraika apa adanya terhadap kondisi atau posisi dari proposisi-proposisi hukum dan non hukum. Teknik argumentatif juga digunakan dalam penelitian ini, dalam pembahasan selanjutnya dapat memberikan argumen-argumen hukum dan dilakukan teknik sistematif, dalam upaya mencari kaitan rumusan suatu konsep hukum atau proposisi hukum atara peraturan perundang-undangan yang sederajat maupun yang dibawahnya.

\section{PEMBAHASAN}

\section{Ketentuan Pengaturan Perseroan Terbatas dalam Hukum Nasional}

Pada mulanya PT diatur dalam KUHD yang sudah berumur lebih dari seratus tahun. Selama perjalanan waktu tersebut telah banyak terjadi perkembangan ekonomi dan dunia usaha, baik nasional maupun internasional. Hal ini tidak sesuai lagi dengan tuntutan perkembangan. Disamping itu, diluar KUHD masih terdapat pula pengaturan badan hukum semacam PT bagi golongan bumi putra sehingga menimbulkan dualisme badan hukum perseroan yang berlaku bagi warga negara Indonesia. ${ }^{14}$

14 Abdulkadir Muhammad, 2010, Hukum Perusahaan Indonesia, Citra Aditya Bakti, Bandung, h. 104 
Untuk mengatasi hal ini dan memenuhi kebutuhan hukum yang sesuai dengan tuntutan perkembangan dan pembangunan nasional sudah tiba waktunya mengadakan pembaharuan hukum tentang PT.

Ketentuan KUHD tentang PT itu tidak berlaku lagi setelah keluarnya Undang-undang No. 1 Tahun 1995 tentang PT yang diundangkan pada tanggal 7 Maret 1995, Undang-undang tersebut mencabut Pasal 36-56 KUHD dan berikut segala perubahannya terakhir dengan Undang-undang Nomor 4 Tahun 1971 dan Stb. Nomor 569 dan Nomor 717 Tahun 1939 tentang Ordonansi Maskapai Andil Indonesia. Undang-undang Nomor 1 Tahun 1995 terdiri dari 12 bab dengan 129 Pasal dan berlaku satu tahun kemudian terhitung sejak tanggal diundangkan.

Meningkatnya kebutuhan masyarakat akan layanan cepat, kepastian hukum serta tuntutan akan perkembangan dunia usaha yang sesuai dengan prinsip pengelolaan perusahaan yang baik (good corporate govermance) menuntut penyempurnaan dan penggantian Undang-undang Nomor 1 Tahun 1995. Oleh karena itu, Undang-undang Nomor 1 Tahun 1995 disempurnakan dan diganti dengan Undang-undang Nomor 40 Tahun 2007 tentang Perseroan Terbatas, yang diundangkan melalui Lembaran Negara Nomor 106 Tahun 2007. Undang-undang ini mulai berlaku pada tanggal diundangkan. Diundangkan di Jakarta pada tanggal 16 Agustus 2007. Undang-undang Nomor 40 Tahun 2007 terdiri dari 14 bab dengan 161 pasal. Pada saat berlakunya Undang-undang 40 Tahun 2007 tentang Perseroan Terbatas, Undang-undang Nomor 1 Tahun 1995 dicabut dan dinyatakan tidak berlaku lagi. Kini Undang-undang yang mengatur PT adalah Undang-undang No. 40 Tahun 2007 tentang PT.

\section{Dualisme Pengaturan Mengenai Penetapan Modal dasar Perseroan Terbatas}

\section{Penetapan Modal Dasar Perseroan Terbatas Menurut Undang- Undang Nomor 40 Tahun 2007}

Secara khusus badan usaha PT diatur dalam Undang-undang Nomor 40 Tahun 2007 selanjutnya disingkat UUPT tentang Perseroan Terbatas, yang secara efektif berlaku sejak 16 Agustus 2007. Sebelum berlakunya UUPT 2007, berlaku UUPT No. 1 Tahun 1995 yang berlaku sejak 7 Maret 1996 sampai dengan 15 Agustus 2007. Undang-Undang No. 
40 Tahun 2007 telah disesuaikan dengan berbagai perkembangan yang terjadi dalam aktivitas usaha berupa penambahan ketentuan baru, perbaikan penyempurnaan maupun mempertahankan ketentuan yang ada dari Undang-Undang sebelumnya yang dinilai masih relevan dengan keadaan saat ini. ${ }^{15}$

Klausula penetapan modal Perseroan Terbatas dalam UUPT disebutkan sebagai berikut dalam pasal: ${ }^{16}$

\section{Pasal 31}

(1) Modal dasar Perseroan Terdiri atas seluruh nilai nominal saham.

(2) Ketentuan sebagaimana dimaksud pada ayat (1) tidak menutup kemungkinan peraturan perundang-undangan di bidang pasar modal mengatur modal Perseroan terdiri atas saham tanpa nilai nominal.

\section{Pasal 32}

(1) Modal dasar perseroan paling sedikit Rp. 50.000.000,00 (lima puluh juta rupiah)

(2) Undang-undang yang mengatur kegiatan usaha tertentu dapat menentukan jumlah minimum modal perseroan yang lebih besar daripada ketentuan modal dasar sebagaimana dimaksud pada ayat (1).

(3) Perubahan besarnya modal dasar sebagaimana dimaksud pada ayat (1), ditetapkan oleh Peraturan Pemerintah.

\section{Pasal 33}

(1) Paling sedikit 25\% (dua puluh lima persen) dari modal dasar sebagaimana dimaksud dalam Pasal 32 harus ditempatkan dan disetorkan penuh

(2) Modal ditempatkan dan disetor penuh sebagaimana dimaksud pada ayat (1) dibuktikan dengan bukti penyetoran yang sah.

(3) Pengeluaran saham lebih lanjut yang dilakukan setiap kali untuk menambah modal yang ditempatkan harus disetor penuh

\section{Penetapan Modal Dasar Pendirian PT Menurut Peraturan Pemerintah Nomor 29 Tahun 2016}

Tahun 2016 dikeluarkan Peraturan Pemerintah No. 29 Tahun 2016 Jakarta,h. 9

15 Binoto Nadapdap, 2012, Hukum Perseroan Terbatas, Permata Aksara, ${ }_{16}$ Undang-undang Nomor 40 Tahun 2007 tentang Perseroan Terbatas 
tentang Perubahan Modal Dasar Perseroan Terbatas. Lewat aturan terbaru ini, ketentuan modal dasar PT yang semula paling sedikit Rp. 50.000.000,00 (lima puluh juta rupiah) menjadi sepenuhnya diserahkan kepada kesepakatan para pendiri Perseroan Terbatas. Sebagaimana yang telah ditentukan dalam Pasal 1 ayat (3) Peraturan Pemerintah No. 29 Tahun 2016.

Pasal 1 ayat (1) aturan tersebut sebatas mengatur kewajiban setiap PT untuk memiliki modal dasar. Pada ayat selanjutnya hanya mengamanatkan bahwa modal dasar harus dituangkan dalam anggaran dasar yang dimuat dalam akta pendirian Perseroan Terbatas. Sementara mengenai besaran minimal modal dasar tidak diatur secara tegas sebagaimana diatur sebelumnya melalui Undang-undang No. 40 Tahun 2007. Lewat aturan terbaru ini aturan besaran minimal modal dasar perseroan "disimpangi" dan diserahkan sepenuhnya pada kesepakatan para pendiri Perseroan Terbatas. Jika ditelaah kembali dalam Pasal 32 ayat (3) Undang-undang No. 40 tahun 2007 memang 'membuka peluang' untuk mengubah besaran modal dasar lewat Peraturan Pemerintah. Ketentuan ini dibuat untuk mengantisipasi perubahan keadaaan ekonomi yang dinamis.

Namun menurut hemat penulis pemerintah luput memperhatikan aspek perlindungan terhadap pihak ketiga atas perubahan penetapan modal dasar tersebut. Yang pada awalnya pengaturan modal dasar Rp. 50.000.000,00 (lima puluh juta rupiah) agar pihak ketiga terlindungi ketika melakukan kerjasama atau mitra kerja dengan suatu Perseroan Terbatas. Potensi lain yang menjadi isu lanjutan adalah mengenai melebarnya pertanggungjawaban harta pribadi, misalnya nanti adanya sengketa dengan pihak ketiga (dalam hal ini berarti pihak yang diajak bekerjasama dengan PT tersebut) tetapi aset perusahaan tidak menutupi utang dengan pihak ketiga, yang akhirnya untuk menutupi utang itu sampai harus terbawa hingga harta pribadi meskipun tanggung jawab PT normalnya hanya sebatas modal yang ditanamkan.

Mengacu pada penjelasan Peraturan Pemerintah Nomor 29 Tahun 2016 Tentang Perubahan Modal Dasar Perseroan Terbatas, Pasal 1 ayat (3) yang menentukan:

"Penentuan besaran modal dasar Perseroan Terbatas berdasarkan 
kesepakatan, para pendiri Perseroan Terbatas adalah upaya menghormati asas kebebasan berkontrak yang memberikan kebebasan kepada masyarakat untuk mengadakan perjanjian dalam mendirikan Perseroan Terbatas berdasarkan ketentuan hukum perdata."

Menurut penulis bahwa modal dasar dalam PT bukan merupakan kesepakatan yang berlandaskan asas kebebasan berkontrak, karena penetapan modal dasar dalam PT merupakan keputusan/penetapan (beschikking), yang mana tujuannya adalah menjamin perlindungan pihak ketiga yang akan bekerjasama dengan PT. Penentuan kualifikasi modal dasar dalam PT sebagai refleksi bahwa PT tersebut sehat dalam manajemen dan operasional.

Arti beschikking dari pemerintah adalah penetapan tertulis yang diproduksi oleh Pejabat Tata Usaha Negara, mendasarkan diri pada peraturan perundang-undangan yang berlaku. Penjelasan keputusan Tata Usaha Negara (beschikking), menurut Pasal 1 angka 3 Undang-Undang Nomor 5 Tahun 1986 tentang Peradilan Tata Usaha Negara, didefinisikan sebagai berikut:

"Keputusan Tata Usaha Negara adalah suatu penetapan tertulis yang dikeluarkan oleh Badan atau Pejabat Tata Usaha Negara yang berisi tindakan hukum Tata Usaha Negara berdasarkan peraturan perundang-undangan yang berlaku, bersifat konkret, individual dan final, yang menimbulkan akibat hukum bagi seseorang atau badan hukum perdata"

Dalam melaksanakan fungsinya, aparat pemerintah selain melaksanakan Undang-undang juga dapat melaksanakan perbuatanperbuatan lain yang tidak diatur dalam Undang-undang. Mengenai hal ini Philipus M. Hadjon menerangkan bahwa pada dasarnya pemerintah tidak hanya melaksanakan Undang-undang tetapi atas dasar fries ermessen/kebebasan bagi pemerintah atau admninistrasi negara dapat melakukan perbuatan-perbuatan lainnya meskipun belum diatur secara tegas dalam Undang-undang.

Dalam hal ini harus adanya penetapan/beschikking dari pemerintah nominal dari penetapan modal dasar dari pembentukan PT, tidak terjadinya tindakan sewenang-wenang berdasarkan kesepakatan para pihak yang 
akan mendirikan perusahaan. Tujuan dari adanya ketetapan aturan ini untuk menjamin adanya kepastian hukum para pihak yang terlibat dalam kerjasama antar pihak dan eksistensi perusahaan tersebut.

\section{Analisis Mengenai Peraturan Tentang Penetapan Modal Dasar PT Antara Undang-Undang No. 40 Tahun 2007 Dengan Peraturan Pemerintah No. 29 Tahun 2016}

Perbedaan menentukan penetapan modal dasar tersebut diatas dapat menimbulkan implikasi hukum dalam praktek pendirian suatu perseroan yang kelak akan dijadikan dasar pembuatan akta pendirian Perseroan Terbatas.

Indonesia menganut ajaran yang dikemukakan oleh Hans Kelsen, mesti diingat bahwa secara tata urutan perundang-undangan norma yang diatur dalam Peraturan Pemerintah seharusnya sejalan dengan norma yang diatur dengan Undang-undang diatasnya, dalam hal ini Undangundang No. 40 Tahun 2007.

Sistem perjenjangan norma di Indonesia diimplementasikan kedalam Undang-undang No. 12 tahun 2011 tentang Pembentukan Peraturan Perundang-undangan dalam Pasal 7 ayat (1) mengatur mengenai tata urutan peraturan perundang-undangan. Terjadinya konflik antara peraturan perundang-undangan, antara undang-undang dengan kebiasaan, akan berlaku asas-asas prefensi yaitu: lex specialis derogat legi generalis, lex posteori derogat legi priori, atau lex superior derogat legi inferiori. ${ }^{17}$

Terjadinya konflik norma antara Undang-undang No. 40 Tahun 2007 dengan Peraturan Pemerintah No. 29 Tahun 2016 mengenai modal dasar tersebut diatas, apabila dikaji berdasarkan atas asas Lex superior derogat legi inferiori sebagai pisau analisanya maka peraturan perundangundangan yang mengatur penetapan modal awal adalah Undang-undang No. 40 Tahun 2007 yang memiliki kekuatan hukum lebih tinggi.

Terkait dengan kepastian hukum dalam peraturan mengenai PT hendaknya memberikan peraturan yang jelas agar tidak adanya konflik norma dalam hierarki peraturan tersebut agar nantinya tidak terjadi kekuasaan yang sewenang-wenang. Untuk itu teori kepastian hukum

17Zainudin Ali, 2008, Filsafat Hukum, Sinar Grafika, Jakarta,h.118 
dipergunakan apabila suatu peraturan dibuat dan diundangkan serta diatur secara jelas dan logis.

Berdasarkan teori sistem hukum dari Friedman sistem hukum terdiri dari struktur hukum, substansi hukum, dan budaya hukum. Dalam permasalahan ini aspek substansi hukum yang penulis gunakan untuk menganalisa karena hukum yang hidup dimasyarakat perlu juga dijadikaan pertimbangan untuk pemberlakuan norma-norma hukum seperti sistem peradilan yang pada hakikatnya adalah "sistem normatif" atau "sistem penegakan substansi hukum", dalam hal ini integrated legal system yang didalamnya adalah substansi hukum wajib mengisi peraturan perundangundangan dengan norma yang bersifat tegas mengenai peraturan penetapan modal Perseroan Terbatas.

\section{Perlindungan Hukum Pihak Ketiga Dalam Melakukan Kerjasama Dengan Perseroan Terbatas}

\section{a. Perlindungan Hukum}

Adanya hubungan hukum yang terjadi antara PT dengan pihak ketiga menciptakan adanya perlindungan hukum dalam melakukan kerjasama.

Teori yang digunakan dalam kasus ini adalah teori perlindungan hukum oleh Philipus M. Hadjon yang membedakan perlindungan hukum bagi rakyat dalam 2 (dua) macam yaitu: ${ }^{18}$

1. Perlindungan hukum reprensif artinya ketentuan hukum dapat dihadirkan sebagai upaya pencegahan terhadap tindakan pelanggran hukum. Upaya ini diimplementasi dengan membentuk aturan hukum yang bersifat normatif.

2. Perlindungan hukum yang preventif bertujuan untuk mencegah terjadinya sengketa yang mengarah tindakan pemerintah bersikap hatihati dalam pengambilan keputusan berdasarkan diskresi. Perlindungan hukum yang reprensif bertujuan untuk menyelesaikan terjadinya sengketa termasuk penanganan lembaga peradilan.

Perlindungan reprensif dalam peneitian ini berarti mengacu pada ketentuan hukum untuk pencegahan terjadinya sengketa. Dengan melaksanakan peraturan-peraturan yang jelas dan tidak menimbulkan

${ }_{18}$ Op.cith.29 
multitafsir yang nantinya dapat menimbulkan perlindungan hukum yang lemah.

Perlindungan preventif diartikan subjek hukum (yang mempunyai hak dan kewajiaban untuk bertindak dalam hukum) yang dimaksud dalam penelitian ini antara PT dengan pihak ketiga (yang bekerjasama).

\section{b. Perlindungan Hukum Pihak Ketiga Dalam Melakukan Kerjasama Dengan Perseroan Terbatas}

Dalam rangka meningkatkan tegaknya keadilan dan mencegah ketidakwajaran, pada keadaan atau peristiwa tertentu, konsep Piercing The Corporate Veil, mempunyai misi utama yaitu untuk mencapai keadilan khususnya bagi pihak ketiga dengan pihak perusahaan yang mempunyai hubungan hukum tertentu. Seperti halnya dalam konteks ini perlindungan hukum pihak ketiga dengan perseroan terbatas yang melakukan kerjasama. ${ }^{19}$

Salah satu teori penerapan piercing the corporate veil dilakukan dalam hal penerapan kontraktual yang juga layak diterapkan jika ada hubungan kontraktual antara perusahaan dengan pihak ketiga. Tanpa penerapan teori ini, kerugian terhadap pihak ketiga tidak mungkin tertannggulangi. Agar dapat diterapkan teori piercing the corporate veil dalam hubungan dengan kontrak pihak ketiga ini, biasanya dipersyaratkan terdapat unsur keadaan yang tidak lazim pada aktivitas perusahaan. Keadaan tidak lazim tersebut dapat berupa salah satu dari fakta-fakta seperti permodalan perusahaan yang tidak dinyatakan dengan benar/tidak adanya kepastian tentang permodalan tersebut.

Dalam melakukan kerjasama ini, pihak direksi perseroan yang melakukan kontrak kerjasama harus sangat berhati-hati dalam menguraikan cara penyelesaian hak dan kewajiban terhadap pihak ketiga. Klausul penyelesaian jika terjadinya sengketa harus tercantum pada perjanjian yang dilakukan. Sejauh mana tanggungjawab perseroan yang terdapat dari kontrak kerjasama tersebut. Karena menurut Undang-undang No. 40 Tahun 2007 Pasal 3 Ayat 1 menyatakan, pemegang saham PT tidak bertanggungjawab secara pribadi atas perikatan yang dibuat atas

${ }_{19}$ M. Yahya Harahap, 2009, Hukum Perseroan Terbatas, Sinar Grafika, Jakarta, h. 76. 
nama perseroan dan tidak ditanggungjawabkan atas kerugian perseroan melebihi saham yang dimiliki. Dari pengertian ini sudah jelas bila terjadinya sengketa utang pemegang saham tidak bertanggung jawab atas terjadinya hal tersebut. Pasal ini mempertegas ciri dari perseroan bahwa pemegang saham hanya bertanggungjawab sebesar setoran atas seluruh saham dan tidak meliputi harta kekayaan pribadi. Oleh sebab itu maka diperlukan aturan dari penetapan modal dasar yang jelas untuk para pemegang saham untuk terciptanya kepastian hukum.

\section{c. Penyelesaian Kasus Hukum Antara Perseroan Terbatas Dengan Pihak Ketiga Dalam Penyelesaian Utang Piutang}

Penyelesaian utang-piutang ini bisa melalui jalur pengadilan (litigasi) maupun diluar pengadilan (non-litigasi).

Penyelesaian hutang piutang melalui jalur pengadilan antara lain:

a. Gugatan perdata biasa;

b. Arbitrase;

c. Proses kepailitan dan atau PKPU;

Sedangkan dalam penyelesaian utang piutang diluar pengadilan antara lain dapat menggunakan Alternative Dispute Resolution (ADR). ${ }^{20}$ Sengketa hutang-piutang merupakan sengketa perdata dipertegas dalam beberapa yurisprudensi, antara lain berdasarkan Putusan Mahkamah Agung tanggal 11 Maret 1970 No. 93 K/Kr/1969 yang secara tegas dan tegas menyatakan "Sengketa tentang hutang piutang merupakan sengketa perdata". Jadi penjelasan sengketa hutang piutang harus menempuh jalur perdata.

Dalam kerjasama dengan PT yang terlibat hutang piutang, jika ingin menuntut haknya berupa pembayaran hutang dapat ditempuh jalur pengadilan. Dasar hukumnya adalah Kitab Undang-Undang Hukum Perdata dengan dalil wanprestasi.

20 Manahan M.P. Sitompul, 2009, "Penyelesaian Sengketa Utang-piutang Perusahaan Dengan Perdamaian Di Dalam Atau Di Luar Proses Kepailitan (Studi Mengenai Lembaga Penundaan Kewajiban Pembayaran Utang)", Desertasi, Sekolah Pascasarjana Universitas Sumatera Utara, h. 56 


\section{PENUTUP}

\section{Simpulan}

Peraturan mengenai penetapan modal dasar pendirian PT sebagaimana yang dimaksud dalam Undang-Undang No. 40 Tahun 2007 adalah yang paling memiliki kekuatan hukum karena di Indonesia menganut Teori Jenjang Norma/ Stuffen Teori dari Hans Kelsen peraturan yang dibawahnya harus sejalan dengan peraturan yang diatasnya. Sesuai juga dan ditegaskan dengan asas Lex superior derogat legi inferiori artinya peraturan perundang-undangan yang lebih tinggi mengenyampingkan berlakunya peraturan perundang-undangan yang lebih rendah tingkatannya.

Perlindungan hukum untuk pihak ketiga dalam kerjasama dengan PT dalam membuat kontrak kerjasama harus sangat berhati-hati dan membuat klausul perjanjian secara jelas baik dalam menguraikan cara penyelesaian hak dan kewajiban terhadap pihak dan kasus hukum penyelesaian utang piutang. Secara Undang-undang No. 40 Tahun 2007 Pasal 3 Ayat 1, pemegang saham PT tidak bertanggungjawab secara pribadi atas perikatan yang dibuat atas nama perseroan dan tidak ditanggungjawabkan atas kerugian perseroan melebihi saham yang dimiliki.

\section{Saran}

Sebaiknya pemerintah merevisi Undang-Undang No. 40 Tahun 2007 tersebut karena sudah tidak sejalan dengan perkembangan perekonomian saat ini dan mencabut Peraturan Pemerintah No. 29 Tahun 2016 karena dengan dikeluarkan pengaturan tentang kebebasan penetapan besaran penetapan modal berpotensi menimbulkan permasalahan yaitu: tidak adanya kepastian hukum bagi pihak ketiga/mitra kerja yang diajak bekerjasama yang seolah-olah menyimpangi UndangUndang Perseroan Terbatas Undang-undang No. 40 Tahun 2007. Yang secara hierarki peraturan seharusnya peraturan yang dibawahnya harus sejalan dengan peraturan yang berada diatasnya.

Untuk masyarakat yang hendak memulai usaha, jika secara permodalan belum tercapai angka minimal 50.000.000,00 (Lima puluh juta rupiah), sebaiknya memilih jenis wadah hukum lain yang sesuai dengan 
aset yang dimiliki. Didalam menetapkan modal tersebut pihak yang memulai usaha harus berinteraksi dengan pihak ketiga (yang diajak bekerjasama) untuk dilindungi dengan jumlah minimal. Jika penetapan modal sesuai dengan ketentuan Peraturan Pemerintah No. 29 Tahun 2016 yang dinyatakan di bebaskan kepada pendiri perseroan/logikanya diturunkan dari ketentuan Undang-Undang, penulis berpendapat justru kondisi tersebut tidak memberikan sama sekali kepastian hukum bagi setiap pihak.

\section{DAFTAR PUSTAKA}

\section{Buku:}

Ali, Zainudin 2008, Filsafat Hukum, Sinar Grafika, Jakarta 2010, Metode Penelitian Hukum, Sinar Grafika, Jakarta

Dirjosisworo, Soedjono 1997, Hukum Perusahaan Mengenai Bentukbentuk Perusahaan (Badan Usaha) di Indonesia, Mandar Maju Bandung

Dahlan, dan Sanusi Bintang, 2000, Pokok-pokok Hukum Ekonomi dan Bisnis, Citra Aditya Bakti Bandung.

Harjono, Dhaniswara 2007, Hukum Penanaman Modal Tinjauan Terhadap Pemberlakuan Undang-undang No. 25 Tahun 2007 Tentang Penanaman Modal Edisi Pertama, Rajawali

Hadikusuma Sutantya R. dan Sumantoro, 1995, Pengertian Pokok Hukum Perusahaan: Bentuk-Bentuk Perusahaan yang Berlaku di Indonesia, Edisi ke-1 Cetakan ke-3, Raja Grafindo Persada, Jakarta

Harahap, M. Yahya 2009, Hukum Perseroan Terbatas, Sinar Grafika, Jakarta. Pers, Jakarta

Muhammad, Abdulkadir 2002, Hukum Perusahaan Indonesia, Citra Aditya Bandung 2004, Hukum dan Penelitian Hukum, Citra Aditya Bakti, Bandung

Aditya Bakti, Bandung

Nadapdap Binoto, 2012, Hukum Perseroan Terbatas, Permata Aksara, Jakarta

Nasution, Bahder Johan 2008, Metode Penelitian Hukum, Mandar Maju, 
Bandung

Philip J. Scaletta Jr., dalam Zaman Hadi, 2011, Karakteristik Tanggung Jawab Pribadi Pemegang Saham, Komisaris dan Direksi dalam Perseroan Terbatas, UB Press, Malang

Rido, R. Ali 1986, Hukum Dagang tentang Aspek-aspek Hukum dalam Asuransi Udara, Asuransi Jiwa dan Perkembangan Perseroan Terbatas, Remadja Karya, Bandung

Widjaya, I.G Rai 2000, Hukum Perusahaan dan Undang-undang dan Peraturan Pelaksana di Bidang Usaha, KBI, Jakarta

Wicaksono, Frans Satrio 2009, Tanggungjawab Pemegang Saham, Direksi, dan Komisaris PT(PT), Visimedia, Jakarta

\section{Peraturan Perundang-Undangan:}

Undang-Undang Nomor 40 Tahun 2007 tentang Perseroan Terbatas

\section{Sumber Dari Penelitian IImiah:}

M.P. Sitompul, Manahan 2009, "Penyelesaian Sengketa Utang-piutang Perusahaan Dengan Perdamaian Di Dalam Atau Di Luar Proses Kepailitan (Studi Mengenai Lembaga Penundaan Kewajiban Pembayaran Utang)", Desertasi, Sekolah Pascasarjana Universitas Sumatera Utara 